\title{
Penerapan Data Mining Untuk Analisis Daftar Pembelian Konsumen Dengan Menggunakan Algoritma Apriori Pada Transaksi Penjualan Toko Bangunan MDN
}

\author{
Edo Tachi Naldy \& Andri \\ Fakultas Teknik Ilmu Komputer, Universitas Bina Darma \\ Email: edotn12@gmail.com
}

\begin{abstract}
Everyday the MDN Building Shop has sales transactions but these transactions are only used as data reporting, MDN Building Stores do not manage sales transaction data and analyze a relationship between building material products purchased by consumers in the future. The purpose of this study is to process sales transaction data from consumer purchases by utilizing the Apriori Algorithm, one of the data mining processing methods. From the Apriori algorithm that will be used, it will find an association rule by finding the minimum value of support and confidence. The final result is that if the minimum support value is $50 \%$ and the minimum trust is $90 \%$, then 10 patterns of consumer purchase transactions are obtained with $100 \%$ confidence. From the association rules, it was found that the transactions that occurred were the purchase of Knie In Grest, Tee in grest, gelam 10 x 12, thinner bottles, knie grest 3 in, waving aw pipes, speck gloves, $3 \mathrm{~mm}$ polywood, and 1 nail in a keris.
\end{abstract}

Keywords: Data Mining, Association Rule, Apriori Algorithm.

\section{Pendahuluan}

Pertumbuhan ekonomi masyarakat diiringi dengan pertumbuhan bisnis yang semakin banyak di Indonesia memiliki potensi yang sangat besar bagi pasar ritel. Salah satu jenis pasar modern yang saat ini terus berkembang dengan penawaran harga yang hanya berbeda sedikit, kemudian karena lokasi toko atau gerai yang dekat dengan konsumen serta mengutamakan kepraktisan dan waktu yang tidak lama dalam berbelanja (Elisa, 2018).

Kegiatan perdagangan didalam dunia bisnis selalu mempunyai pola yang dinamis dengan penuh persaingan yang mengharuskan para pelaku bisnis harus menemukan suatu strategi yang dapat meningkatkan penjualan dan pemasaran produk mereka. Dengan adanya kegiatan jual beli maka setiap industry memiliki sebuah data transaksi pembelian dari masing-masing konsumen. Kalau dihitung setiap harinya data transaksi penjualan akan terus meningkat (Megayasa et al, 2016). Oleh karena itu, dalam memanfaatkan data tersebut agar tidak hanya berfungsi sebagai arsip saja maka, diperlukan sebuah pengolahan data dengan pemanfaatan teknologi informasi (TI) yang dapat memberikan informasi yang bermanfaat untuk meningkatkan penjualan.

Meskipun TI khususnya komputasi, telah diadopsi di berbagai bidang, akan tetapi masih banyak industri tidak memanfaatkan secara optimum. Toko ataupun ritel biasanya memiliki data historis transaksi penjualan dari bulan ke bulan, namun hanya digunakan sebagai laporan perminggu dan perbulan. Jika semakin lama dibiarkan, maka akan terjadi pertumbuhan data yang menimbulkan kaya data namun miskin informasi. Data yang tidak diolah ini hanya akan mengakibatkan penumpukan data yang tidak bermanfaat.

Toko maupun ritel sering kali masih menggunakan cara manual dalam strategi pemasaran produknya yang tidak memiliki acuan dan hanya berdasarkan perkiraan. Mekanisme 
seperti ini mengakibatkan rekomendasi produk tidak tepat sasaran. Untuk mendukung strategi pemasaran, perusahaan perlu memanfaatkan teknologi komputasi (Riszky et al, 2019). Data transaksi penjualan yang tersimpan dapat memberikan manfaat untuk manajemen toko, misalnya untuk meningkatkan penjualan melalui strategi penjualan produk yang sesuai.

Toko bangunan MDN merupakan salah satu bidang industri bahan bangunan, yang dimana toko tersebut memiliki data transaksi yang selalu meningkat setiap tahunnya. Akan tetapi pemanfaatan data transaksi pembelian dari konsumen dari produk yang telah dibeli hanya dijadikan bahan pelaporan. Padahal data tersebut dapat diolah menjadi suatu informasi sehingga toko dapat merekomendasikan keterkaitan pembelian barang pada konsumen. Salah satu pengolahan data yang dapat dilakukan menjadi suatu informasi yaitu pemanfaatan Association Rule.

Association rule merupakan metode dari data mining yang dapat mengidentifikasi hubungan kesamaan antar item dan dimanfaatkan sebagai pengetahuan yang nantinya berisi informasi pola yang sering muncul dari data transaksi (SAPUTRO, 2017). Association Rule diimplementasikan pada algoritma apriori yang dapat digunakan untuk membentuk kandidat kombinasi item untuk diterapkan aturan asosiatif yang mempunyai nilai keseringan tertentu. Dalam aturan asosiasi memiliki 2 parameter yaitu minimum support (persentase kombinasi item dari transaksi) dan minimum confidence (kuatnya hubungan antar item dalam aturan asosiatif) (Prabowo, 2019). Setelah melakukan penerapan data mining yang dimana telah menemukan aturan asosiasi dari 2 parameter dari Algoritma Apriori akan diketahui suatu peristiwa dengan menganalisis hasil yang didapat. Analisis merupakan kegiatan yang mengidentifikasi dan menguraikan apa saja yang terjadi untuk menemukan solusi dan fungsi dari kegiatan yang dilakukan (Gho et al, 2019).

Penelitian serupa yaitu Analisis Dan Penerapan Data Mining Pada Transaksi Penjualan Obat Menggunakan Algoritma Apriori Di Apotek Persijam. Apotek ini memiliki data penjualan setiap hari, akan tetapi data tersebut hanya disimpan sehingga menjadi penumpukan. Diperlukannya suatu analisis transaksi penjualan obat dengan menggunakan data mining sebagai suatu teknik analisa data yang dapat membantu apotek memperoleh pengetahuan berupa pola-pola pembelian dalam periode tertentu. Algoritma yang digunakan untuk proses analisis yaitu Algoritma Apriori dengan menggunakan parameter minimum support dan minimum confidence. Dari proses analisis ini dihasilkan aturan asosiasi, pertama Jika membeli minyak, maka juga akan membeli obat sakit kepala dengan nilai Support 0,1 dan nilai confidence sebesar 1 serta nilai accuration 0,96643 (Gho et al, 2019).

Dari penelitian diatas membuktikan bahwa data transaksi dapat dijadikan suatu informasi berupa pola sekaligus analisis dari pengolahan data menggunakan Algoritma Apriori. Penulis akan mengimplementasikan data mining sekaligus menganalisis data transaksi pembelian konsumen pada 4 tahun terakhir dari tahun 2016-2020. Pengolahan data akan dilakukan dengan tools WEKA yang dimana dapat membantu mencari association rule dari Algoritma Apriori yang digunakan. Hasil yang didapatkan nantinya akan berupa suatu informasi pola pembelian konsumen (keterkaitan) sekaligus menganalisis pola (daftar) pembelian yang telah didapatkan.

Dari latar belakang tersebut, maka penulis melakukan penelitian yang berjudul 
"Penerapan Data Mining Untuk Analisis Daftar Pembelian Konsumen Dengan Menggunakan Algoritma Apriori Pada Transaksi Penjualan Toko Bangunan MDN".

\section{Tinjauan Literatur}

\subsection{Data Mining}

Data mining yaitu kegiatan meliputi pengumpulan, pemakaian data historis dalam menemukan keteraturan, pola, atau hubungan dalam dataset berukuran besar. Output dari data mining ini bisa dipakai untuk memperbaiki pengambilan keputusan di masa depan (Suyanto, 2017).

Data mining secara sederhana merupakan teknik menemukan pola yang berguna dalam data, ada beragam definisi dan kriteria untuk data mining. Data mining juga disebut sebagai penemuan pengetahuan, pembelajaran mesin, dan analisis prediktif (Kotu et al, 2014).

Data mining adalah proses yang menggunakan statistik, matematika, kecerdasan buatan, dan machine learning untuk mengekstraksi dan mengidentifikasi informasi yang bermanfaat dan pengetahuan yang terkait dari berbagai database besar (WAHYUDIN, 2019). Data mining dibagi menjadi beberapa kelompok yaitu deskripsi, estimasi, prediksi, klasifikasi, pengklusteran, dan asosiasi.

Dari definisi diatas dapat disimpulkan bahwa Data mining merupakan Teknik pengumpilan, pemakaian data dengan menggunakan statistik, machine learning dalam mengidentifikasi suatu informasi yang bermanfaat.

\subsubsection{Pengelompokkan Data Mining}

Data mining dibagi menjadi 6 kelompok (Gunadi et al, 2016), Adapun penjabarannya yaitu :

1. Deskripsi

Deskripsi dari pola dan kecendrungan sering memberikan kemungkinan penjelasan untuk suatu pola atau kecendrungan dalam data tersebut. Misalkan petuga pengumpulan suara mungkin tidak dapat menemukan keterangan atau fakta bahwa siapa yang tidak cukup professional akan sedikit didukung dalam pemilihan presiden. Klasifikasi Terdapat target variable kategori, misalkan penggolongan pendapatan dapat dipisahkan dalam 3 kategori yaitu pendapatan tinggi, pendapatan sedang dan pendapatan rendah.

2. Estimasi

Estimasi hampir sama dengan klasifikasi, kecuali variable target estimasi lebih mengarah ke angka daripada kekategori. Pemodelan dibentuk menggunakan record lengkap yang menyediakan nilai dari variabel target sebagai nilai prediksi. Dilanjutkan dengan peninjauan berikutnya estimasi nilai dari variabel prediksi.

\section{Prediksi}

Prediksi juga hampir sama dengan klasifikasi dan estimasi, kecuali bahwa dalam predikasi nilai dari hasil akan ada di masa mendatang. Misalkan prediksi dalam bisnis seperti harga beras dalam tiga bulan mendatang, prediksi tingkat pengangguran 5 tahun yang akan datang.

4. Pengklusteran 
Clustering yaitu pengelompokan record, pengamatan atau memperhatikan dan membentuk kelas objek-objek yang memiliki kemiripan. Kluster adalah kumpulan record yang memiliki kemiripan satu dengan yang lainnya dan memiliki ketidakmiripan dengan record-record dalam kluster lain. Pengklusteran berbeda dengan klasifikasi yaitu tidak adanya variabel target dalam pengklusteran. Pengklusteran tidak mencoba untuk melakukan klasifikasi, mengestimasi, atau memprediksi nilai dari variabel target.

5. Asosiasi

Asosiasi berfungsi menemukan atribut yang muncul dalam satu waktu. Dalam dunia bisnis lebih umum disebut analisis keranjang belanja. Contoh asosiasi dalam bisnis yaitu menemukan barang dalam supermarket yang dibeli secara bersamaan dan barang yang tidak pernah dibeli secara bersamaan.

\subsubsection{Tahapan Data Mining}

Data mining merupakan salah satu dari rangkaian Knowledge Discovery in Database $(K D D) . K D D$ berhubungan dengan teknik integrasi dan penemuan ilmiah, interprestasi dan visualisasi dari pola-pola sejumlah kumpulan data (Vulandari, 2017). Berikut 5 tahapan data mining dapat dilihat pada gambar 2.1.

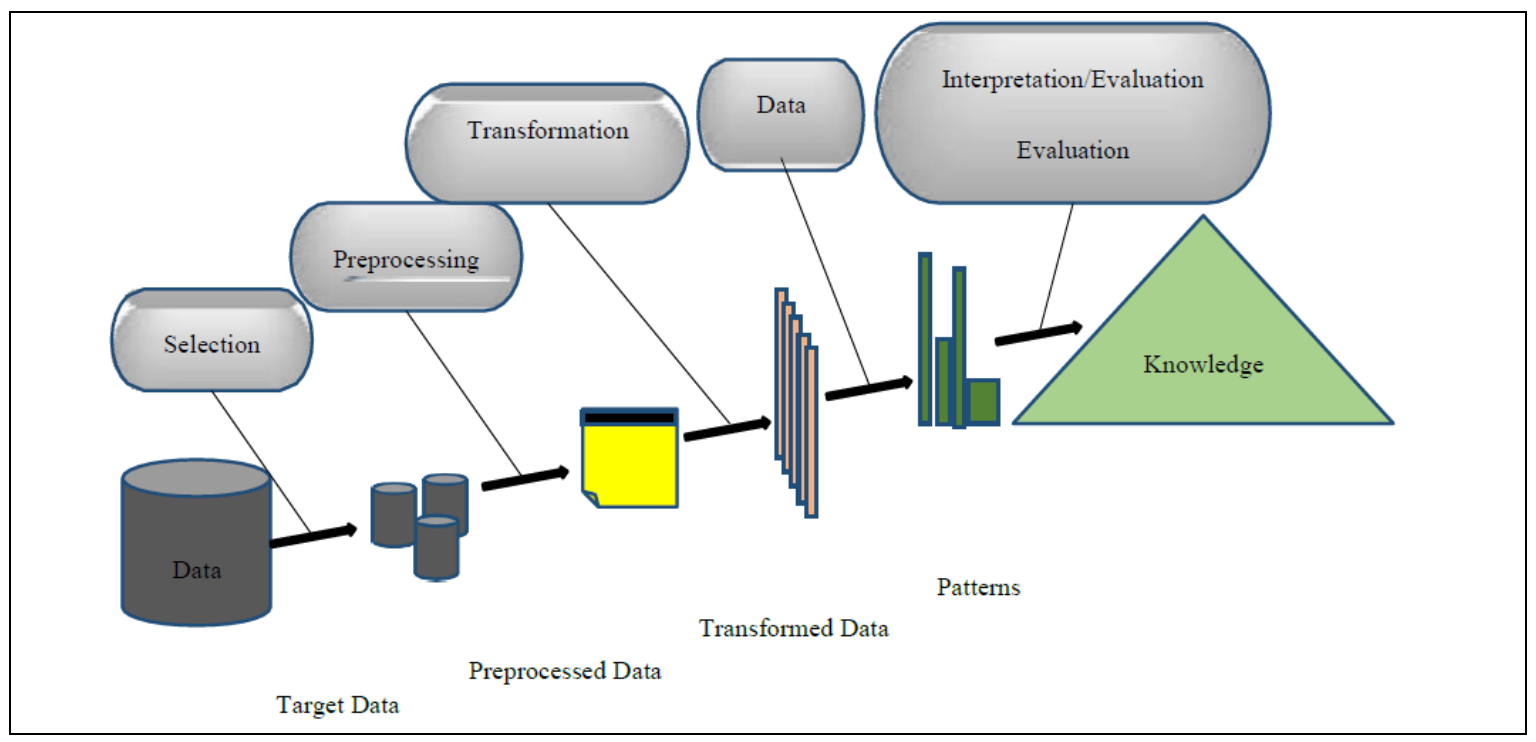

Gambar 2. 1 Tahapan Data Mining

\section{Data Selection}

Data yang ada akan dilakukan seleksi data dan atribut yang akan digunakan untuk proses selanjutnya. Seleksi data dari sekumpulan data operasional dilakukan sebelum tahap penggalian informasi. Data hasil seleksi akan digunakan untuk proses data mining, dan disimpan dalam berkas yang terpisah dari data operasional.

2. Pre-processing (Cleaning)

Tahapan Cleaning merupakan data hasil seleksi yang akan dilakukan pemrosesan pendahuluan dan pembersihan data. Sebelum proses data mining dilakukan, perlunya dilakukan cleaning dengan tujuan untuk membuang duplikasi data, menghilangkan data yang tidak konsisten.

3. Transformation

Merupakan proses transformasi pada data yang telah dipilih untuk diubah menjadi 
bentuk yang sesuai untuk diolah nantinya.

4. Data Mining

Data mining adalah proses mencari suatu informasi atau pola yang menarik pada data yang telah dipilih menggunakan teknik atau metode tertentu. Pemilihan metode atau algoritma sangatlah penting karena sangat berpengaruh pada tujuan dan proses $K D D$ secara keseluruhan.

5. Interpretation (evaluation)

Pada tahap ini, dilakukan identifikasi pola-pola yang dihasilkan dari data mining. Pola informasi yang dihasilkan perlu ditampilkan kedalam bentuk yang mudah dimengerti oleh pihak yang berkepentingan.

\subsection{Analisis}

Analisis yaitu suatu penyelidikan terhadap suatu peristiwa atau perbuatan untuk mengetahui keadaan yang sebenarnya dari sebab dengan mengidentifikasi dan menguraikan apa saja yang terjadi dalam menemukan solusi dan fungsi dari kegiatan tersebut (Purba et al, 2018).

Analisis pada data mining dapat digunakan sebagai penyampaian suatu informasi dari hasil Algoritma yang digunakan. Adapun konsep dari data mining dari integrasi $K D D$ memiliki 5 tahapan yaitu seleksi, pre-processing, Transformasi, data mining, interpretasi \& evaluasi (analisis dari hasil yang didapat) (Yennimar et al, 2019).

Kesimpulan yang didapat bahwa analisis merupakan suatu keadaan dengan mengidentifikasi dan melakukan suatu penguraian dari hasil yang didapat, hasil akhirnya yaitu menemukan suatu solusi dan opsi rekomendasi dari analisis yang dilakukan.

\subsection{Algoritma Apriori}

Algoritma Apriori merupakan salah satu algoritma yang melakukan pencarian frequent itemset dengan menggunakan teknik association rule. Untuk mencari association rule dari kumpulan data, yang harus dilakukan yaitu mencari Frequent itemset terlebih dahulu. Frequent itemset adalah kumpulan item yang sering muncul secara bersamaan. Penting tidaknya suatu asosiasi dapat diketahui dengan dua tolak ukur yaitu nilai support dan nilai confidence. Support adalah nilai penunjang atau persentase dari kombinasi sebuah item dalam database sedangkan confidence adalah nilai kepastian yaitu kuatnya hubungan antar item dalam asosiasi (Santoso et al, 2016).

Algoritma Apriori merupakan algoritma yang paling terkenal yang sering kali digunakan peneliti untuk menemukan pola frekuensi tinggi. Pola frekuensi tinggi adalah pola item yang terdapat di dalam suatu database yang memiliki frekuensi atau support diatas ambang batas tertentu yang disebut dengan istilah minimun support (Hasugian, 2017).

Dari penjelasan diatas dapat disimpulkan bahwa Algoritma Apriori digunakan sebagai teknik asosiasi sederhana yang menentukan pola frequent itemset yang dijalankan pada sekumpulan data. Pada intinya semua aturan asosiasi yang memenuhi syarat minimum untuk support dan syarat minimum untuk confidence (Antoni, Fikari \& Akbar, 2018; Antoni \& Akbar, 2019; Antoni, Herdiansyah, Akbar \& Sumitro, 2021; Antoni, Jie \& Abareshi, 2020).

\subsection{Association Rule}

Association rule mining merupakan teknik data mining yang digunakan untuk 
menemukan aturan suatu kombinasi item. Salah satu tahap analisis asosiasi yang menghasilkan algoritma yang efisien adalah analisis pola frekuensi tinggi (frequent pattern). Suatu asosiasi dapat diketahui dengan adanya dua tolak ukur yaitu support dan confidence (Nursikuwagus et al, 2016).

Association rule mining atau analisis asosiasi adalah teknik suatu data mining untuk menemukan aturan asosiasi antara suatu kombinasi item. Interestingness measure yang dapat digunakan dalam data mining yaitu:

a. Support adalah suatu ukuran yang menunjukan seberapa besar tingkat dominasi suatu item atau itemset dari keseluruhan transaksi.

b. Confidence adalah suatu ukuran yang menunjukkan hubungan antar dua item secara conditional (berdasarkan suatu kondisi tertentu).

Dengan adanya penerapan association rule bertujuan untuk menemukan informasi itemitem yang saling berhubungan dalam bentuk suatu rule, dengan demikian association rule diterapkan pada pola yang sering kali muncul dengan menggunakan Algoritma Apriori. Aturan asosiasi yang berbentuk "if ... then ..."atau "if ... and ... then ..." merupakan pengetahuan yang dihasilkan dari fungsi (Purba et al, 2018).

\subsubsection{Nilai Support}

Tahapan awal yaitu mencari kombinasi item yang memenuhi syarat minimum dari nilai support. Nilai support sebuah item, nilai support sering juga disebut sebagai analisa pola frekuensi tinggi (Gho et al, 2019, dalam Kusrini, et al, 2009), berikut rumus yang digunakan dalam menghitung 1-itemset:

$$
\operatorname{Support}(A)=\frac{\sum \text { Transaksi mengandung } A}{\sum \text { Transaksi }} \times 100 \%
$$

Selanjutnya rumus yang digunakan jika nilai support dari 2 item sebagai berikut.

$$
\operatorname{Support}(A, B)=\frac{\sum \text { Transaksi mengandung } A, B}{\sum \text { Transaksi }} \times 100 \%
$$

\subsubsection{Nilai Confidence}

Dalam aturan asosiasi akan didapatkan nilai kepastian (confidence) Berikut rumus yang akan membentuk aturan asosiasi.

$$
\text { Confidence }(A \mid B)=\frac{\sum \text { Transaksi } A \text { dan } B}{\sum \text { Transaksi } A} \times 100 \%
$$

Rumus diatas menjelaskan bahwa nilai confidence diperoleh dengan cara membagi jumlah transaksi yang mengandung item A dan item B (item pertama bersamaan dengan item yang lain) dengan jumlah transaksi yang mengandung item $\mathrm{A}$ (item pertama atau item yang ada disebelah kiri) (Ristianingrum et al, 2017)

\subsection{WEKA}

Waikato Environment for Knowledge Analysis (WEKA) adalah suatu rangkaian lengkap yang ada diperpustakaan kelas Java yang mengimplementasikan banyak state-of-the-art pembelajaran mesin dan algoritma data mining. Weka tersedia secara bebas di World Wide Web dan menyertai teks baru pada dokumen data mining dan sepenuhnya menjelaskan 
semua algoritma yang dikandungnya (Herman, 2017, dalam Witten et al., 2011).

WEKA merupakan salah satu perangkat lunak yang memiliki banyak algoritma machine learning untuk keperluan data mining. Weka juga memiliki tools yang digunakan untuk pengelohan data, mulai dari pre-processing, classification, regression, clustering, association rules, dan visualization (Firdaus et al, 2020).

\section{Metode Penelitian}

Dalam Metodologi Penelitian ada beberapa poin yang dijelaskan yaitu metode penelitian, dan metode pengumpulan data.

\subsection{Metode Penelitian}

Metode penelitian yang digunakan penulis yaitu penelitian analisis deskriptif dengan pendekatan kuantitatif yang bertujuan menggambarkan secara sistematis fakta-fakta serta hubungan antar variabel yang diselidiki dengan cara mengumpulkan data, mengolah, menganalisis, dan menginterpretasi data (Fauzi, Dencik \& Asiati, 2019), untuk menganalisis daftar pembelian konsumen dari transaksi penjualan di Toko Bangunan MDN. Berikut kerangka penelitian dapat dilihat pada gambar 1.

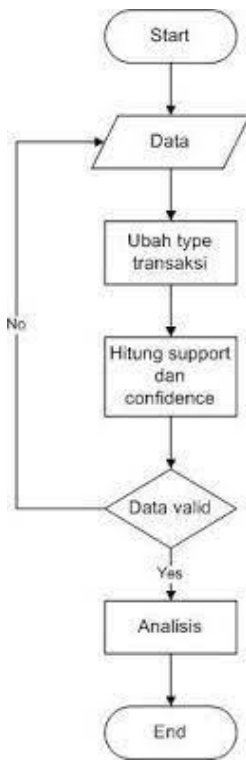

Gambar 1. Alur Penelitian

\subsection{Metode Pengumpulan Data}

Adapun metode pengumpulan data yang digunakan dalam menyelesaikan penelitian ini, antara lain:

\section{Observasi}

Penulis akan melakukan observasi sekaligus dokumentasi ke Toko Bangunan MDN.

2. Wawancara

Penulis juga akan melakukan wawancara untuk mengetahui data-data transaksi penjualan dari Toko Bangunan MDN dari tahun 2016-2020.

3. Studi Pustaka 
Penulis juga mencari penelitian-penelitian terdahulu untuk dijadikan referensi dalam melakukan analisis data.

\subsection{Analisis Pola Frekuensi Tinggi}

Proses utama yang dilakukan dalam Algoritma apriori yaitu mengkombinasikan setiap item sampai tidak terbentuk kombinasi lagi dan hasil dari item tersebut dipangkas dengan menggunakan minimum support. Berikut rumus yang akan digunakan dalam menentukan nilai minimum Support .

$$
\operatorname{Support}(A)=\frac{\sum \text { Transaksi mengandung } A}{\sum \text { Transaksi }} \times 100 \%
$$

Rumus yang akan digunakan untuk 2 kombinasi sebagai berikut.

$$
\operatorname{Support}(A, B)=\frac{\sum \text { Transaksi mengandung A, B }}{\sum \text { Transaksi }} \times 100 \%
$$

Untuk 3 kombinasi Itemset dapat menggunakan rumus seperti berikut.

$$
\operatorname{Support}(A, B, C)=\frac{\sum \text { Transaksi mengandung } A, B, C}{\sum \text { Transaksi }} \times 100 \%
$$

\subsection{Aturan Asosiasi}

Dalam aturan asosiasi akan didapatkan nilai kepastian (confidence) Berikut rumus yang akan membentuk aturan asosiasi

$$
\text { Confidence }(A \mid B)=\frac{\sum \text { Transaksi } A \text { dan } B}{\sum \text { Transaksi } A} \times 100 \%
$$

Untuk aturan asosiatif dengan 3 persamaan Itemset, diperoleh dengan rumus berikut.

$$
\text { Confidence }(A|B| C)=\frac{\sum \text { Transaksi } A, B \text { dan } C}{\sum \text { Transaksi } A} \times 100 \%
$$

\section{Hasil dan Pembahasan}

Pada hasil dan pembahasan akan dilakukannya perhitungan algoritma apriori dengan menggunakan rumus, setelah itu akan diimplementasikan dengan WEKA.

\subsection{Data Selection}

Dari data yang telah didapat dari Toko Bangunan MDN yang telah di eksport kedalam excel, kemudian data akan dijadikan sebagai variabel data. Adapun data yang diambil dari tahun 2016 hingga 2020 berjumlah 2413 transaksi penjualan dari analisis daftar pembelian konsumen. Data awal yang tercatat berupa atribut yaitu kode barang, nama barang, satuan dan qty (quality). Dalam melakukan proses seleksi data, tools yang digunakan adalah Pentaho Data Integration dengan menggunakan $x l s$ file sebagai input, select values sebagai seleksi untuk mendapatkan variabel yang dibutuhkan dalam penelitian yaitu seperti nama barang dan transaksi barang, Microsoft Excel sebagai output. Berikut ini merupakan proses dari seleksi data dapat dilihat pada gambar 2. 


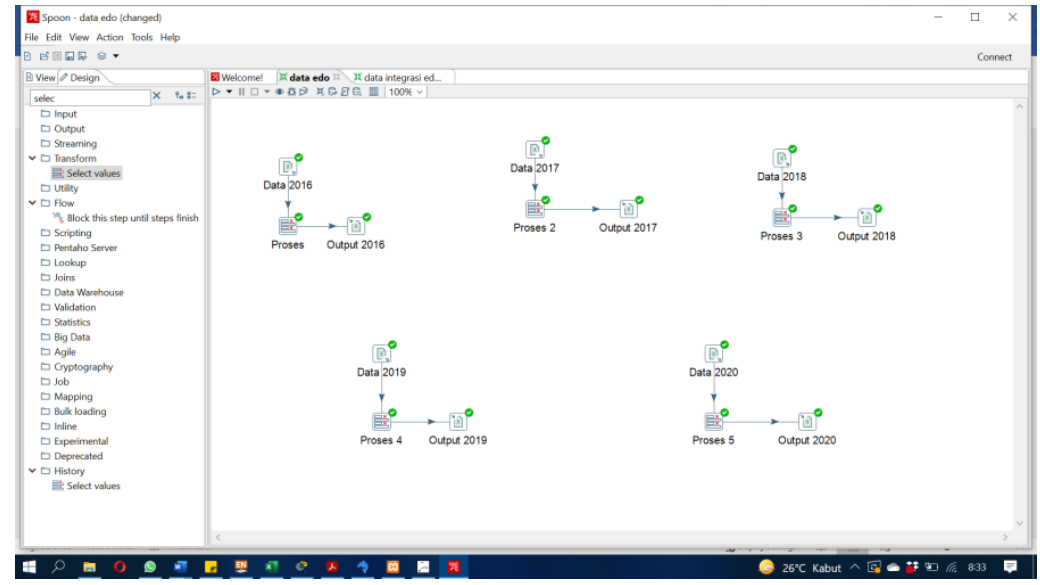

Gambar 2. Proses Seleksi Data

Setelah dilakukan proses seleksi data maka variabel yang tersisa hanya variabel-variabel yang dibutuhkan dalam penelitian yaitu Nama Barang dan transaksi barang

\subsection{Data Integration}

Tahapan setelah melakukan seleksi data yaitu cleaning data dimana data tersebut di proses yang ada di dalam tahapan data mining yaitu pada tahap ini akan dilakukan pembersihan data-data atau penghapusan data yang noise. Proses ini juga bisa digunakan untuk menghilangkan data yang duplicate dan null, memeriksa data yang inkosisten, serta memperbaiki kesalahan yang terjadi di dalam data. Setelah mendapatkan hasil dari pembersihan maka data akan diintegrasikan kembali.

\subsection{Format Tabular}

Dalam perhitungan manual penulis akan menggunakan bilangan biner yaitu 1 dan 0 yang nantinya akan diolah dalam excel [9]. Tabel tabular dapat dilihat pada gambar 3.

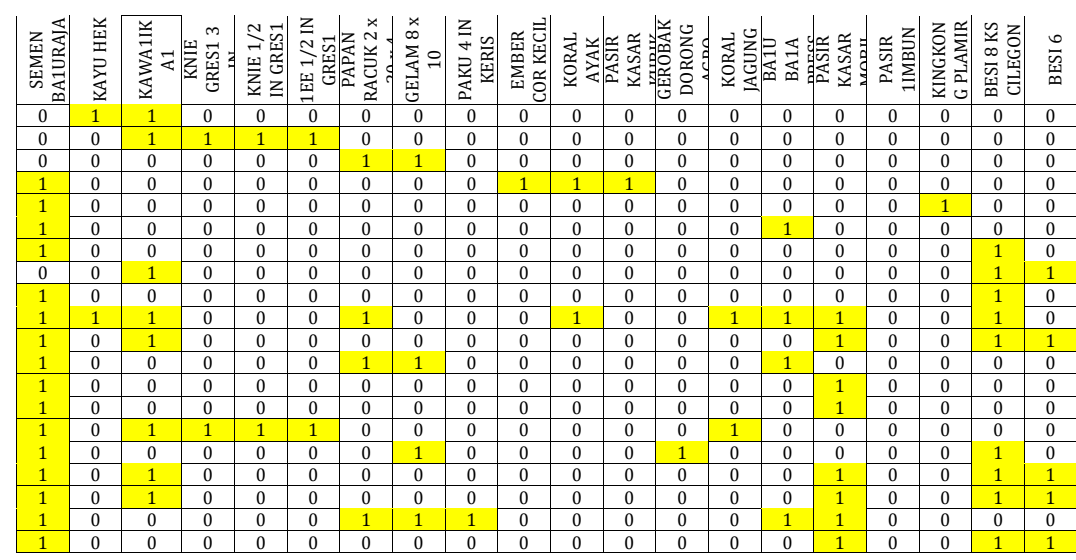

Gambar 3. Format Tabular

\subsection{Implementasi WEKA}

Pada implementasi menggunakan WEKA penulis menggunakan data yang telah digabungkan dari 2016 hingga 2020, dimana data yang didapat berupa 44 jenis barang dengan total transaksi yang dilakukan sebanyak 100 transaksi. Dalam pengimplementasian pada WEKA setiap jenis barang diharuskan membentuk format 
tabular seperti perhitungan algoritma apriori pada bab 3, akan tetapi pendefinisian untuk true or false pada WEKA di inisiasi jika terjadi transaksi disimbolkan dengan huruf (Y) sedangkan tidak terjadinya transaksi di inisiasi dengan huruf $(\mathrm{N})$. Hal ini untuk meminimalisir terjadinya kesalahan pembacaan data pada aplikasi. Berikut identifikasi tipe data yang terjadi pada $W E K A 4$.

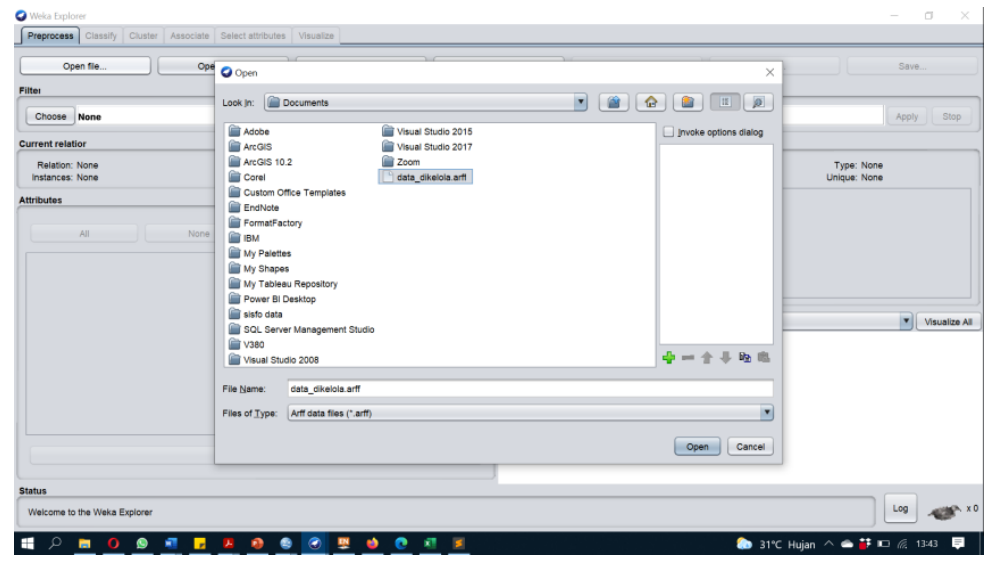

Gambar 4. Identifikasi Tipe Data arff

\subsubsection{Proses Apriori}

Penulis melakukan proses yang dimana masuk dihasil yang akan diproses dengan menentukan nilai minimum support dan minimum confidence. Pada WEKA penulis melakukan konfigurasi yaitu minimum support 50\% dan confidence $90 \%$. Berikut konfigurasi yang dilakukan dalam Algoritma Apriori pada WEKA dapat dilihat pada gambar 5 .

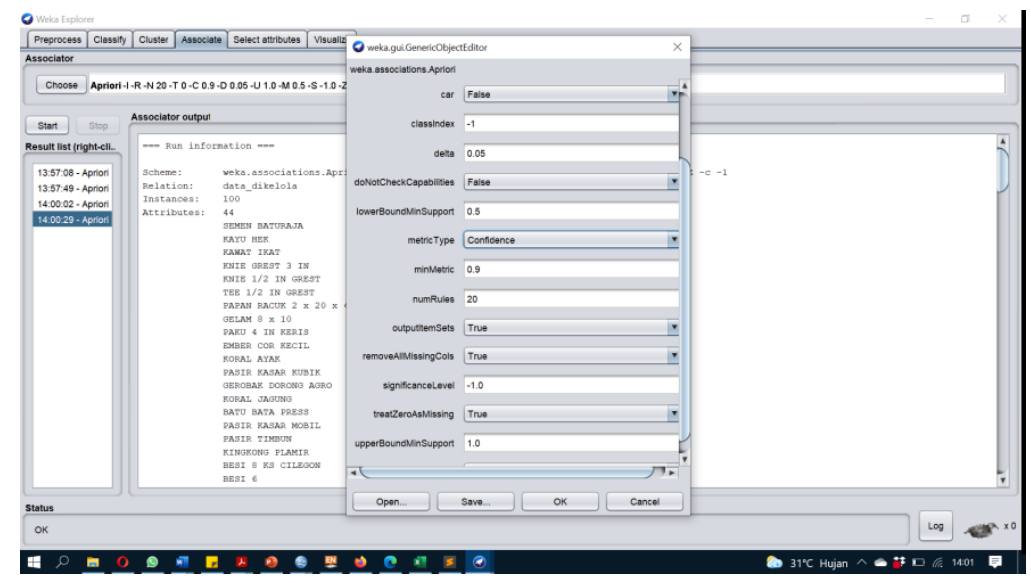

Gambar 5. Proses Konfigurasi Apriori

Setelah melakukan konfigurasi nilai support (50\%) dan confidence (90\%) dengan rules yang ditampilkan nantinya sebanyak 20 aturan asosiasi. Berikut hasil yang didapatkan dari pola transaksi 1 itemset, 2 itemset dan 3 itemset. Dari pembentukkan minimum support yang didapat bahwa ada 20 pola transaksi yang didapatkan. Berikut hasil pola transaksi yang didapatkan dapat dilihat pada gambar 6 . 


\begin{tabular}{l|l|lr} 
J & $\mathbf{N}$ & $\begin{array}{l}\text { JURNAL } \\
\text { NASIONAL }\end{array}$ & Jurnal Nasional Ilmu Komputer \\
ILMU & e-ISSN: 2746-1343 \\
KOMPUTER & $\mathrm{K}$ & Vol. 2, No. 2, Mei 2021 \\
\hline
\end{tabular}

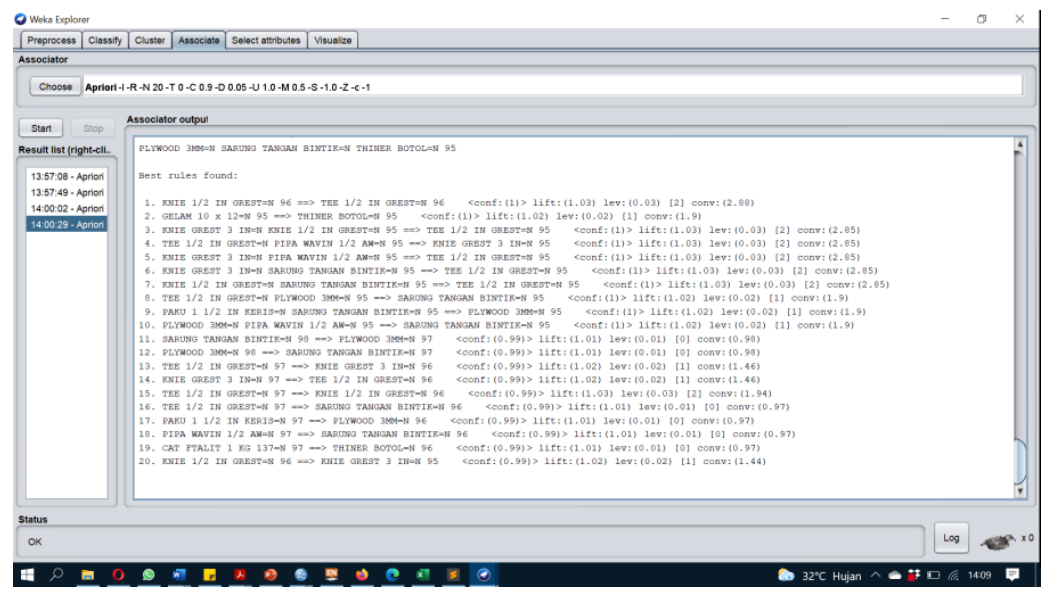

Gambar 6. Hasil Aturan Asosiasi

\section{Kesimpulan}

Berdasarkan hasil penelitian yang sudah dilakukan dan sudah dijelaskan sebelumnya dalam penggunaan Algoritma Apriori untuk menganalisis pola transaksi pembelian konsumen, ada beberapa kesimpulan yang didapatkan dari penelitian sebagai berikut:

1. Berdasarkan hasil data transaksi konsumen dari 2016 hingga 2020 sebanyak 100 transaksi dengan 44 jenis barang bahwa transaksi yang sering terjadi pada pembelian Knie $1 / 2$ In Grest, Tee $1 / 2$ in grest, gelam $10 \times 12$, thiner botol, knie grest 3 in, pipa waving $1 / 2$ aw, sarung tangan bintik, polywood $3 \mathrm{~mm}$, dan paku $1 \frac{1}{2}$ in keris.

2. Perhitungan apriori dengan minimum support 50\% dan minimum confidence $90 \%$ didapatkan 20 pola transaksi dengan nilai confidence $100 \%$ pada 10 transaksi.

3. Penulis merekomendasikan tata peletakan barang dari temuan yang didapatkan agar konsumen dapat dengan mudah mendapatkan kebutuhan sesuai dengan pola transaksi

\section{References}

Anggraini, D., Putri, S. A., \& Utami, L. A. (2020). Implementasi Algoritma Apriori Dalam Menentukan Penjualan Mobil Yang Paling Diminati Pada Honda Permata Serpong. JURNAL MEDIA INFORMATIKA BUDIDARMA, 4(2), 302-308.

Antoni, D., Jie, F., \& Abareshi, A. (2020). Critical factors in information technology capability for enhancing firm's environmental performance: case of Indonesian ICT sector. International Journal of Agile Systems and Management, 13(2), 159-181.

Antoni, D., \& Akbar, M. (2019). E-supply chain management value concept for the palm oil industry. Jurnal Sistem Informasi, 15(2), 15-29.

Antoni, D., Fikari, D., \& Akbar, M. (2018). The readiness of palm oil industry in enterprise resource planning. Telkomnika, 16(6), 2692-2702.

Elisa, E. (2018). Market Basket Analysis Pada Mini Market Ayu Dengan Algoritma Apriori. Jurnal Resti (Rekayasa sistem dan Teknologi Informasi), 2(2), 472-478.

Firdaus, F., \& Mukhlis, A. (2020). Implementasi Algoritma Naive Bayes Pada Data Set Kualitatif Prediksi Kebangkrutan. JURIKOM (Jurnal Riset Komputer), 7(1), 15-20.

Fauzi, F., Dencik, A. B., \& Asiati, D. I. (2019). Metodologi Penelitian untuk manajemen 
dan akuntansi. Jakarta: Salemba Empat.

Gho, E., Abidin, D. Z., \& Rasywir, E. (2019). ANALISIS DAN PENERAPAN DATA MINING PADA TRANSAKSI PENJUALAN OBAT MENGGUNAKAN ALGORITMA APRIORI DI APOTEK PERSIJAM. Jurnal Ilmiah Mahasiswa Sistem Informasi, 1(1), 56-64.

Gunadi, G., \& Sensuse, D. I. (2016). Penerapan metode data mining market basket analysis terhadap data penjualan produk buku dengan menggunakan algoritma apriori dan frequent pattern growth (fp-growth): studi kasus percetakan pt. Gramedia. Telematika MKOM, 4(1), 118-132.

Hasugian, P. M. (2017). Pengujian Algoritma Apriori Dengan Aplikasi Weka Dalam Pembentukan Asosiation Rule. Jurnal Mantik Penusa, 1(2).

Herman, H. (2017). Analisis Pola Pemilihan Konsentrasi Ilmu Jurusan Sistem Informasi Di STMIK TIME. Jurnal TIMES, 6(2), 37-43.

Kotu, V., \& Deshpande, B. (2014). Predictive analytics and data mining: concepts and practice with rapidminer: Morgan Kaufmann.

Megayasa, I. G. P., Aryanto, I. K. A. A., Diputra, I. G. S., Arianta, I. N., Rusditya, S., \& Indrawan, G. (2016). Implementasi Algoritma Apriori untuk Menganalisis Pola Pembelian Konsumen pada Produk SPA.

Nursikuwagus, A., \& Hartono, T. (2016). Implementasi algoritma apriori untuk analisis penjualan dengan berbasis web. Simetris: Jurnal Teknik Mesin, Elektro dan Ilmu Komputer, 7(2), 701-706.

Prabowo, Y. (2019). IMPLEMENTASI DATA MINING UNTUK MENENTUKAN POLA PEMBELIAN OBAT PADA APOTIK PANASEA MENGGUNAKAN ALGORITMA APRIORI. STIKOM DINAMIKA BANGSA,

Purba, B. R. B., Hasibuan, N. A., Ginting, G. L., \& Suginam, S. (2018). Implementasi Algoritma Apriori Untuk Mencari Relasi Pada Transaksi Pembelian Alat-Alat Kesehatan. JURIKOM (Jurnal Riset Komputer), 5(3), 269-277.

Ristianingrum, R., \& Sulastri, S. (2017). Implementasi Data Mining Menggunakan Algoritma Apriori.

Riszky, A. R., \& Sadikin, M. (2019). Data Mining Menggunakan Algoritma Apriori untuk Rekomendasi Produk bagi Pelanggan. Jurnal Teknologi dan Sistem Komputer, 7(3), 103-108.

Santoso, H., Hariyadi, I. P., \& Prayitno, P. (2016). Data Mining Analisa Pola Pembelian Produk Dengan Menggunakan Metode Algoritma Apriori. SEMNASTEKNOMEDIA ONLINE, 4(1), 3-7-19.

SAPUTRO, C. D. (2017). Sistem Rekomendasi Pembuatan Paket Menu Dengan Teknik Market Basket Analysis Menggunakan Algoritma Apriori Pada Rumah Makan Kampung Laut Semarang.

Srikanti, E., Yansi, R. F., Norhavina, N., Permana, I., \& Salisah, F. N. (2018). Penerapan Algoritma Apriori Untuk Mencari Aturan Asosiasi Pada Data Peminjaman Buku Di Perpustakaan. Jurnal Ilmiah Rekayasa dan Manajemen Sistem Informasi, 4(1), 77-80. 
Suyanto, D. (2017). Data Mining untuk klasifikasi dan klasterisasi data. Bandung: Informatika Bandung.

Vulandari, R. T. (2017). DATA MINING Teori dan aplikasi Rapidminer. Surakarta: Penerbit Gava Media.

WAHYUDIN, M. (2019). PENENTUAN PENJUALAN PRODUK MINUMAN BERNUTRISI TERLARIS DENGAN ALGORITMA C4. 5 PADA PT. NUTRIFOOD INDONESIA.

Yennimar, Y., Sibarani, E. C., Irwansyah, I., Rahmadi, M. I. T., \& Syahputra, R. (2019). IMPLEMENTASI KESESUAIAN OBAT PADA PENYAKIT MENGGUNAKAN ALGORITMA APRIORI. Jurnal Mantik Penusa, 3(1.1).

\section{Copyrights}

Copyright for this article is retained by the author(s), with first publication rights granted to the journal.

This is an open-access article distributed under the terms and conditions of the Creative Commons Attribution license (http://creativecommons.org/licenses/by/4.0/) 